\title{
IDENTIFIKASI DAN UJI RESISTENSI Staphylococcus aureus TERHADAP ANTIBIOTIK (CHLORAMPHENICOL DAN CEFOTAXIME SODIUM) DARI PUS INFEKSI PIOGENIK DI PUSKESMAS PROPPO
}

\author{
Ratno Budiyanto $^{1 *}$, Novrynda Eko Satriawan ${ }^{1}$, Asdwi Suryani ${ }^{2}$ \\ ${ }^{1}$ Kimia, FMIPA, Institut Sains dan Teknologi Annuqayah, Jl. Bukit Lancaran PP. Annuqayah, Sumenep \\ ${ }^{2}$ Analis, Laboratorium Bina Husada, Jl. Dirgahayu No.33, Pamekasan \\ *email : ratno@istannuqayah.ac.id
}

Received 16 November 2021

Accepted 4 Desember 2021

\begin{abstract}
Abstrak
Pemberian antibiotik pada pasien yang mengalami infeksi piogenik pada kulit di puskesmas proppo belum berdasarkan pada pola kuman dan sensitifitas antibiotik. Penelitian ini bertujuan untuk mengidentifikasi, isolasi serta uji sensitifitas bakteri terhadap beberapa antibiotik sehingga dapat diketahui jenis antibiotik yang paling paten untuk bakteri Staphylococcus aureus. Hasil pengamatan pada isolat pus menunjukkan adanya Staphylococcus aureus dengan ciri kesesuaian. Agar diperoleh bakteri murni dengan jumlah maksimum maka dilakukan isolasi. Telah berhasil diisolasi dan diidentifikasi ke-4 isolat pus yang tumbuh dan memfermentasi pada plat mannitol salt agar, sel berbentuk bulat bergerombol dan bersifat gram positif baik melalui pewarnaan maupun uji secara biokimia. Hasil uji terhadap Chloramphenicol memiliki nilai rata-rata daya hambat $24.0 \mathrm{~mm}$ dengan persentase penggunaan mencapai $75.0 \%$, sedangkan untuk Cefotaxime sodium memiliki nilai rata-rata zona hambat $10.9 \mathrm{~mm}$ dengan persentase penggunaan mencapai $25.0 \%$. Dapat disimpulkan bahwa ke-4 isolat tersebut kesemuanya diidentifikasi sebagai Staphylococcus aureus dengan zona hambat masing-masing isolat sebesar $23.5 \mathrm{~mm}, 24.2 \mathrm{~mm}, 24.0 \mathrm{~mm}$ dan $24.3 \mathrm{~mm}$ yang menunjukkan sensitif terhadap Chloramphenicol sedangkan zona hambat terhadap Cefotaxime sodium masing-masing isolat adalah $5 \mathrm{~mm}, 10.5 \mathrm{~mm}, 14.5 \mathrm{~mm}$ dan $13,5 \mathrm{~mm}$ yang menunjukkan resisten terhadap penggunaan antibiotik tersebut.
\end{abstract}

Kata kunci: PUS, resistensi, Staphylococcus aureus, antibiotik

\begin{abstract}
The administration of antibiotics to the patients with pyogenic skin infections at the Proppo Public Health Center has not been based on bacterial patterns and antibiotic sensitivity yet. This study aims to identify, isolate, and test the sensitivity of several antibiotics so that the most patent antibiotics for Staphylococcus aureus can be identified. The results of observations on pus isolates show the presence of Staphylococcus aureus with appropriate characteristics. In order to make pure bacteria with the maximum number, isolation is carried out. It has been isolated and identified the 4 isolates of pus growing and fermenting on mannitol salt agar plates, the cells are round in clusters and gram positive both through staining and biochemical tests. The test result for Chloramphenicol has an average value of inhibition of $24.0 \mathrm{~mm}$ with a percentage of use reaching $75.0 \%$, while for Cefotaxime sodium has an average value of inhibition zone of $10.9 \mathrm{~mm}$ with a proportion of use reaching $25.0 \%$. It can be said that the 4 isolates are all identified as Staphylococcus aureus, with inhibitory zones of $23.5 \mathrm{~mm}, 23.0 \mathrm{~mm}, 24.0 \mathrm{~mm}$, and $24.3 \mathrm{~mm}$ respectively, indicating sensitivity to chloramphenicol while the inhibitory zone against Cefotaxime sodium, each
\end{abstract}


isolate is $5 \mathrm{~mm}, 10.5 \mathrm{~mm}, 12.5$ and $12.5 \mathrm{~mm}$ which shows resistance to the use of these antibiotics.

Keywords: PUS, resistance, Staphylococcus aureus, antibiotics

\section{Pendahuluan}

Nanah (pus) merupakan zat kuning keputihan yang berasal dari sel darah putih yang telah mati dan membusuk, biasanya banyak ditemukan di bagian daerah yang terinfeksi. Hampir rata-rata santri yang mondok di dunia pesantren mengalami gatal-gatal yang mengakibatkan terjadinya inflamasi pada daerah tangan dan kaki disertai keluar nanah. Biasanya diproduksi pada saat terjadi inflamasi piogenik yang telah terinfeksi oleh kuman maupun bakteri (Singh et al., 2013). Ada beberapa jenis spesies bakteri terhadap pembentukan nanah pada infeksi piogenik yang tersebar di permukaan tubuh manusia seperti luka kulit, infeksi pada telinga maupun abses pada otak. Kesemuanya termasuk jenis spesies bakteri dan jamur yang berbeda. Diantara bakteri yang paling banyak umum ditemukan pada infeksi piogenik tersebut adalah Staphylococcus aureus, Klebsiella spp., Pseudomonas spp, Escherichia coli dan streptococci (Androulla, 1989)

Staphylococcus aureus termasuk jenis bakteri yang sering umum ditemukan terhadap penyakit infeksi piogenik, biasanya bakteri ini berbentuk bulat dengan garis tengah lebih kurang $1 \mu \mathrm{m}$, susuan sel bergerombol sedangkan dari biakan cair terlihat sebagai sel tunggal atau tersusun berpasangan tetrad atau berderet seperti rantai, Staphylococcus tidak bergerak dan tidak membentuk spora (Jawetz et al,1991). Komplikasi yang terjadi pada infeksi piogenik dan jaringan lunak dikarenakan Staphylococcus aureus merupakan masalah klinis yang paling utama. Munculnya strain baru yang lebih komplek ditengarai menjadi penyebab utama terjadinya resistensi terhadap antibiotik sehingga penanganan dan penggunaannya harus sesuai dengan informasi yang tepat sasaran terhadap kepekaan bakteri tersebut.

Agen antimikroba bagian dari salah satu jenis obat umum yang paling banyak digunakan. Penggunaan yang tidak tidak tepat sasaran menyebabkan meluasnya agen antimikroba muncul sebagai obat patogen yang bisa memicu timbulnya resistensi terhadap antibiotik, sehingga dapat memicu akan kebutuhan obat baru. Namun, perkembangan obat antimikroba mulai menurun seiring dengan adanya agen antimikroba baru yang telah banyak digunakan kedalam praktik klinis setiap tahunnya. Mengurangi penggunaan antibiotik yang tidak tepat sasaran dianggap sebagai cara terbaik untuk mengendalikan resistensi. Keberadaan letak geografis yang berbeda menjadikan permasalahan terhadap penggunaan antibiotik, hal ini bisa jadi menimbulkan berbagai macam jenis bakteri yang ditemukan, sehingga obat yang digunakan kemungkinan besar resisten terhadap penyakit piogenik tertentu (Akhi, et al., 2014).

Penelitian ini dilakukan di puskesmas proppo khususnya pada santri yang masuk kategori piogenik infeksi kulit pada tangan maupun kaki dengan tujuan untuk mengetahui keberadaan bakteri Staphylococcus aureus pada pus serta mengetahui kerentanan terhadap penggunaan dua jenis antibiotik.

\section{Metode Penelitian}

\section{Sampel}

Sampel yang digunakan berupa spesimen isloat pus pada pasien yang mengalami piogenik di Puskesmas Proppo Pamekasan, kemudian di isolasi untuk culture. Media pertumbuhan bakteri yang digunakan meliputi manitol salt agar (MSA), Muller Hilton Agar (MHA), dan bahan lain yang digunakan meliputi disk 
antibiotik (Chloramphenicol, Cefotaxime sodium $10 \mu \mathrm{g}), \mathrm{NaCl}$ fisiologis, alkohol $70 \%$, $\mathrm{H} 2 \mathrm{O} 2$, satu set bahan pewarnaan Gram terdiri dari crystal violet, lugol, alkohol 95\%, dan aquades.

\section{Pewarnaan Gram}

Pewarnaan Gram berfungsi untuk mengamati sifat Gram dan morfologi bakteri. Caranya adalah (1). Sampel bakteri diulas diatas object glass lalu difiksasi di atas bunsen, kemudian di angin-anginkan dan ditetesi dengan crystal violet $2 \%$ (didiamkan 1-2 menit). (2). Dibilas dengan air mengalir, kemudian seluruh preparat ditetesi dengan larutan lugol selama 30 detik. (3). Larutan lugol dibilas dengan air mengalir dan preparat dilunturkan dengan Aseton Alkohol (1:3) sampai semua zat warna luntur, dan segera cuci dengan air mengalir. (4). Teteskan dengan zat warna safranin 0,25\%, biarkan selama 2 menit lalu bilas dengan air mengalir kemudian dibiarkan kering, amati di bawah mikroskop dengan pembesaran lensa objektif 100x memakai emersi (Sarudji et al., 2017). Staphylococcus aureus merupakan bakteri Gram positif dan berbentuk kokus bergerombol (Ibrahim, 2017).

\section{Uji Gula Manitol}

Uji manitol bertujuan untuk membedakan apakah Staphylococcus tersebut bersifat patogen atau tidak, caranya ialah dengan menginokulasikan biakan pada media dan diinkubasi $\left(37^{\circ} \mathrm{C}\right.$, 24 jam). Bakteri dikatakan positif jika terlihat perubahan warna menjadi kuning, sebaliknya (negatif) apabila warnanya tetap merah (Ibrahim, 2017).

\section{Uji Katalase}

Tujuan dari uji katalase ini adalah untuk mengetahui aktifitas katalase pada bakteri yang diuji. Caranya ialah dengan mengambil 1 mata ose koloni dari media yang diletakan pada objek glass steril, ratakan koloni jangan sampai menumpuk, kemudian ditetesi dengan 1-2 tetes $\mathrm{H}_{2} \mathrm{O}_{2}$
$3 \%$, dan diamati ada atau tidaknya gelembung, jika ada maka uji katalase positif (Toelle dan Lenda, 2014).

\section{Uji Koagulase}

Pada uji koagulase bertujuan untuk mendeteksi adanya pembentukan enzim koagulase yang terikat pada dinding sel bakteri. Uji ini dilakukan dengan cara mengambil isolat bakteri menggunakan ose, uji koagulase metode slide dilakukan dengan menggunakan plasma sitrat. Reaksi positif pada uji koagulase ditunjukkan dengan adanya gumpalan seperti gel pada preparat, dan reaksi ini dinyatakan negatif jika tidak terdapat gumpalan (Brückler et al., 1994).

\section{Antibiogram/Antibakteri}

Pengujian sensitifitas dilakukan sebagai bentuk keefektifan penggunaan antibiotik. Antibiogram ini menggunakan metode Kirby-Bauer yaitu dengan cara mengambil koloni bakteri uji yang telah ditumbuhkan selama 24 jam sebelumnya dan disuspensikan ke dalam $0,5 \mathrm{ml}$ media cair kemudian di inkubasi selama 5-8 jam. Kemudian suspensi bakteri tersebut ditambahkan $\mathrm{NaCl} \quad 0,85 \%$ hingga mencapai kekeruhan, selanjutnya dengan menggunakan lidi kapas steril suspensi bakteri dioleskan (swab) secara merata pada media MHA dan letakkan paper disk yang sebelumnya telah berisi agen antibiotik di atas media tersebut dan diinkubasi selama 24 jam. Pengamatan dilakukan dengan melihat ada tidaknya zona hambat di sekeliling paper disk tersebut dimana adanya zona hambat menunjukkan adanya aktifitas antibakteri terhadap bakteri uji (Sarudji, 2017).

\section{Hasil dan Pembahasan}

Penelitian ini bertujuan untuk identifikasi, isolasi dan uji resistensi Staphylococcus aureus terhadap Chloramphenicol dan Cefotaxime sodium dari isolat pus infeksi piogenik. Adapun beberapa macam perlakuaannya ialah sebagai berikut: 


\section{Isolasi Bakteri Staphylococcus aerous}

Berdasarkan penelitian Ekawati, E.R (2018) sampel berupa pus yang di ambil dengan metode swab pada permukaan kulit dan di pupuk pada media Nutrient Agar (NA) yang sebelumnya dimasukkan pada media transport, hal ini dilakukan karena isolat tidak langsung diidentifikasi. Setelah itu isolat masih dilakukan penanaman pada media nutrient agar yang bertujuan untuk memberikan nutrisi pada bakteri. Sebetulnya isolat bisa langsung diidentifikasi sebagai screening awal, hanya saja perlakuan ini dilakukan untuk mengetahui keberadaan berbagai jenis bakteri yang terdapat pada isolat.

Untuk skala penelitian seperti ini, isolasi penting untuk dilakukan mengingat hampir rata-rata pasien yang mengalami inflamasi piogenik hingga mengeluarkan nanah di puskesmas Proppo diberikan antibiotik tanpa melihat letak geografis dan informasi terlebih dahulu terhadap spektrum bakteri penyebab dari infeksi dan pola kepekaan bakteri terhadap antibiotik. Oleh sebab itu, perlu dilakukan isolasi bakteri target agar pemberian antibiotik benar-benar berdasarkan pada pola kuman dan sensitifitas terhadap jenis antibiotik yang digunakan. Untuk memperoleh informasi tepat guna sasaran perlu dilakukan isolasi pada media NA yang merupakan nutrisi bagi bakteri agar tumbuh dan berkembang biak sehingga didapatkan koloni dalam jumlah yang banyak untuk kebutuhan isolasi sebagai screening tahap awal. Kemudian koloni dipupuk kembali pada media MSA serta diinkubasi pada suhu $37^{\circ} \mathrm{C}$ selama 24 jam. Keberlangsungan pemupukan pada media MSA bertujuan untuk mendapatkan koloni yang lebih baik sebagai media selektif untuk kebutuhan isolasi yang lebih banyak terhadap sampel yang akan digunakan. Koloni yang tumbuh dengan ciri- ciri bundar, halus, menonjol, berkilau dan berwarna kuning emas tua diduga Staphylococcus aureus. Penanaman pada media Manitol Salt Agar (MSA), bakteri tampak (Gambar 1) terlihat dari warna kemerahan berubah menjadi kuning keemasan yang diduga Staphylococcus aureus.

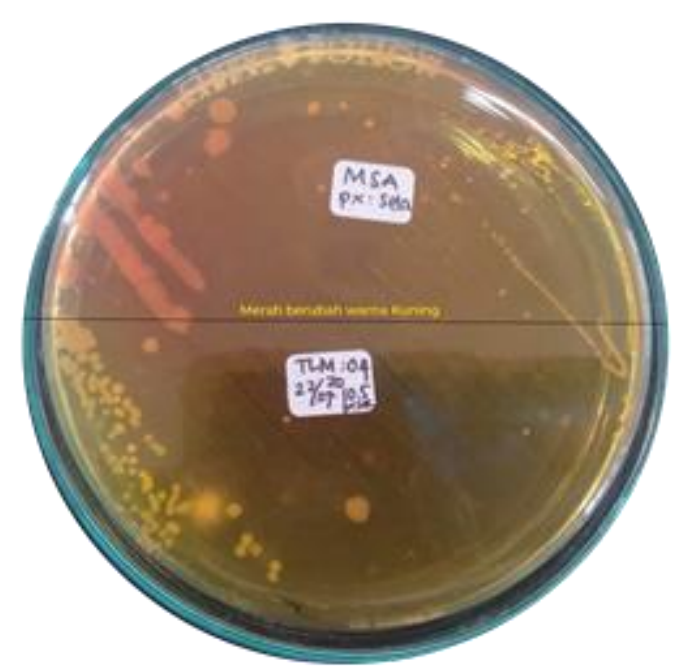

Gambar 1. Profil setelah dilakukan teknik isolasi yang di pupuk pada media MSA

Kemampuan memfermentasi mannitol menyebabkan koloni tampak berwarna kuning. Sebaliknya, bakteri yang tidak mampu memfermentasi akan tampak telihat zona kemerahan. Sebagai screening awal sudah mulai tampak terlihat bahwa koloni tersebut bakteri target. Sehingga untuk mengetahui apakah bakteri yang terdapat pada media tersebut Staphylococcus aureus atau tidak, maka dilakukan screening secara visual dibawah mikroskop dengan cara pewarnaan gram. 


\section{Pewarnaan Gram}

Pewarnaan gram digunakan untuk melihat bentuk bakteri di bawah mikroskop dan membuktikan bahwa bakteri tersebut merupakan gram positif, hal ini dikarenakan bakteri gram positif menyerap warna ungu. Hasil dari empat sampel isolat yang diisolasi didapatkan sampel positif berwarna ungu, berbentuk coccus. Pengecetan dilakukan dengan empat tahapan. Setiap tahapan pada objek glass dilakukan rentan waktu yang berbeda mulai 1-2 menit, setiap perlakuan dibilas menggunakan aquades.

Teknik pewarnaan gram didasarkan atas perbedaan struktur diferensial dinding sel. Pewarnaan terhadap gram positif penting dilakukan mengingat keberadaan Staphylococcus aeuroues tersusun dari satu jenis molekul saja yang terdiri dari 90\% peptidoglikan yang begitu tebal, sehingga ketika didehidrasi dengan alkohol pori dinding sel akan menutup dan menjaga kompleks kristal violet-iodin menjadi tetap di dalam sel. Hal inilah yang menyebabkan bakteri gram posistif dapat mempertahankan zat warna, sehingga Staphylococcus aeuroues tampak terlihat ungu-violet ketika dilihat dibawah mikroskop.

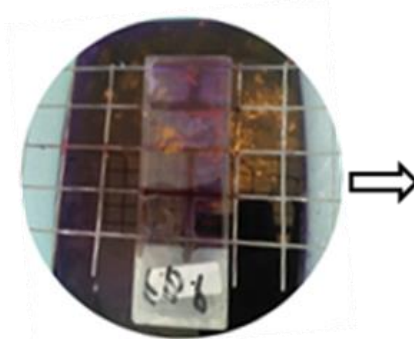

A

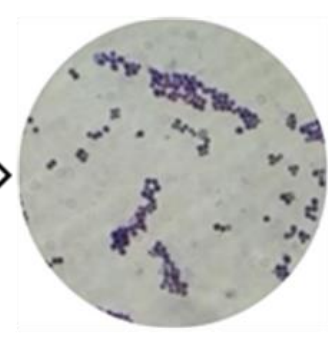

B
Gambar 2. Profil : A. Pewarnaan preparat; B. Hasil pengamatan preparat pada mikroskop

Hasil penelitian secara fisiologis terhadap uji pewarnaan gram isolat tampak terlihat galur gram positif kokus Staphylococcus aureus yang memiliki karakteristik berbentuk bulat dengan diameter $0,5-1,0 \mu \mathrm{m}$, berpasangan dan bergerombol seperti buah anggur (Gambar 2). Warna ungu yang dipertahankan hingga sedemikian rupa meskipun ditetesi beberapa lautan peluntur tidak pernah lepas dari kompleksitas dari zat warna kristal violet-iodium. Perbedaan ini juga dipengaruhi oleh dinding sel Staphylococcus aureus yang tebal sehingga daya absorbsi sangat besar. Retnowati et al. (2011) menyatakan bahwa Staphylococcus aureus merupakan gram positif yang memiliki lapisan peptidoglikan tebal sehingga sangat ketika dilakukan pewarnaan sangat sulit untuk terdegradasi.

\section{Uji Katalase dan Koagulase}

Uji Katalase dilakukan dengan meneteskan hidrogen peroksida $\left(\mathrm{H}_{2} \mathrm{O}_{2}\right)$ $3 \%$ pada benda kaca yang bersih. Biakan dioleskan yang sudah ditetesi hidrogen peroksida dengan usa pada benda kaca tersebut. Suspensi dicampur secara perlahan menggunakan usa, hasil yang positif ditandai dengan terbentuknya gelembung-gelembung udara (Hadioetomo, 1990). Uji katalase dikatakan posistif apabila terbentuknya gelembung gas pada kaca benda (Gambar 3A). Staphylococcus aureus termasuk bakteri yang menghasilkan enzim katalase yang mampu menghidrolisis hidrogen peroksida $\left(\mathrm{H}_{2} \mathrm{O}_{2}\right)$ menjadi air dan gas $\mathrm{O}_{2}$. Uji katalase penting dilakukan untuk mengidentifikasi kelompok bakteri tertentu.

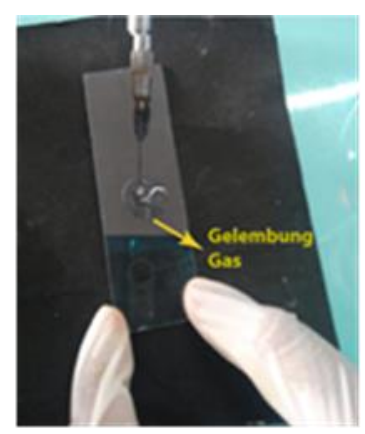

A

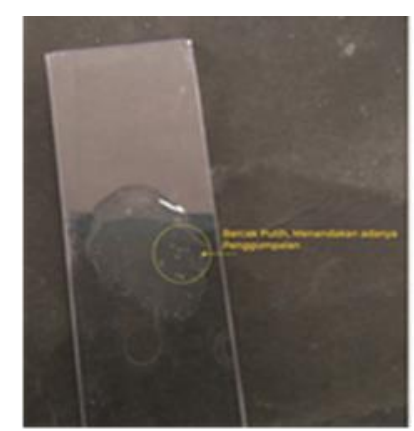

B
Gambar 3. Profil : A. uji katalase positif ; B. uji koagulase positif 
Setelah dilakukan uji katalase, untuk membuktikan bahwa isolat tersebut benarbenar Staphylococcus aureus maka dilanjutkan dengan uji koagulase. Koagulase merupakan salah satu protein yang dapat menggumpalkan sitrat dengan bantuan suatu faktor yang terdapat dalam serum atau termasuk protein ekstraseluler yang dihasilkan yang dihasilkan oleh Staphylococcus aureus yang dapat menggumpalkan plasma (Dewi, 2014). Uji koagulase dilakukan menggunakan uji slide. Uji ini digunakan untuk mengetahui adanya ikatan koagulase. Uji slide dikerjakan dengan cara meneteskan aquadest atau $\mathrm{NaCl}$ fisiologis steril yang diletakkan pada kaca benda, kemudian satu usa biakan yang diuji, disuspensikan. Setetes plasma diletakkan di dekat suspensi biakan tersebut, keduanya dicampur dengan menggunakan usa dan kemudian digoyangkan. Reaksi positif terjadi apabila dalam waktu 2-3 menit terbentuk presipitat granuler (Brückler et al., 1994).

Berdasarkan penelitian Freney (1999) semua galur staphylococcus adalah katalase dan koagulase positif. Berikut ini merupakan hasil ke empat uji katalase dan koagulase positif dapat dilihat pada Tabel 1.

Tabel 1. Hasil uji identifikasi bakteri Staphylococcus aureus

\begin{tabular}{cccc}
\hline \multirow{2}{*}{ Isolat } & \multicolumn{3}{c}{ Uji identifikasi } \\
\cline { 2 - 4 } & Pewarnaan gram & Uji katalase & Uji koagulase \\
\hline PX.A & Coccus-ungu & + & + \\
PX.B & Coccus-ungu & + & + \\
PX.C & Coccus-ungu & + & + \\
PX.D & Coccus-ungu & + & + \\
\hline
\end{tabular}

\section{Sensitifitas}

Sensitifitas dilakukan guna mengetahui seberapa besar tingkat ke efektifan atau sensitifnya terhadap obat yang digunakan sebagai antibiotik dalam upaya penanggulangan tingkat keberhasilan terinfeksinya patogen piogenik pada luka kulit. Uji sensifitas dilakukan untuk melihat sifat resistensi Staphylococcus aureus terhadap beberapa antibiotik. Sensivitas antibotik diperoleh melalui pengukuran zona hambat yang terbentuk setelah proses penempelan cakram antibiotik. Pada penelitian ini digunakan 2 jenis cakram antibiotik, yaitu Chloramphenicol dan Cefotaxime sodium, penelitian ditunjukkan dengan perbedaan diameter zona hambat dalam satuan $\mathrm{mm}$ seperti yang tampak seperti Gambar 4 . Hasil tersebut kemudian dibandingkan dengan tabel standart nasional klinik laboratorium. Bakteri dikatakan resisten, intermediet terhadap antibiotik apabila diameternya antara 16-22 $\mathrm{mm}$, dan sensitif apabila diameternya $\geq 23 \mathrm{~mm}$ (Clinical and Laboratory Standart Institute, 2004). 


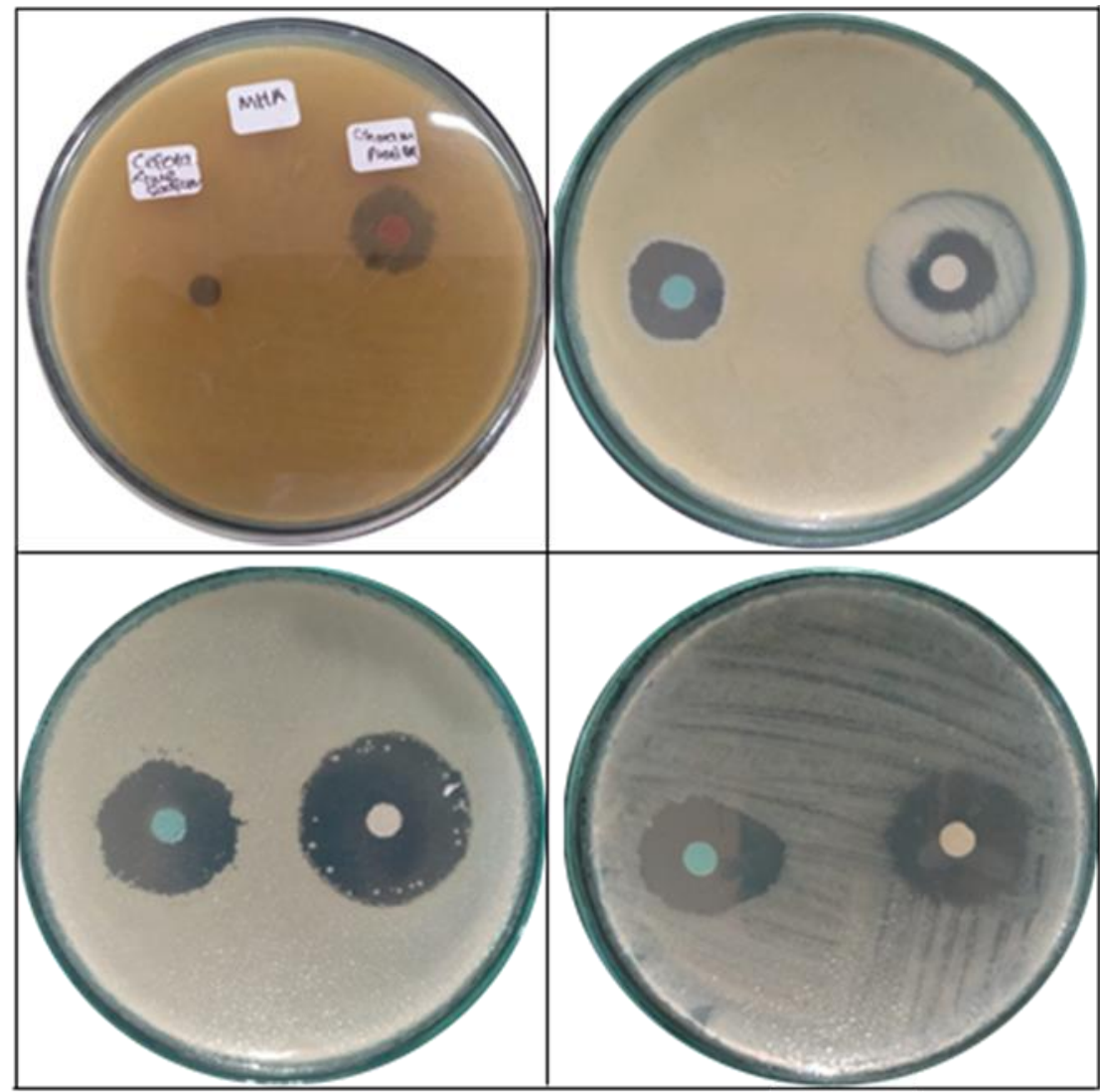

\section{$\bigcirc=$ Chloramphenicol $\bigcirc$ Cefotaxime sodium}

Gambar 4. Profil hasil biogram zona hambat terhadap dua antibiotik

Sensitifitas menunjukkan bahwa antibiotik tersebut memiliki daya hambat yang lebih besar dari kriteria yang seharusnya, intermediet berada pada rentang minimum terendah hingga mencapai sensitifitas, dan resisten menunjukkan daya hambat yang terbentuk berada jauh di bawah kriteria yang telah ditentukan (Kemenkes, 2011).
Berdasarkan uji sensitifitas hasil ratarata diameter zona hambat terhadap dua antibiotik (Tabel 2) sebagian besar isolat Staphylococcus aureus sensitif terhadap Chloramphenicol. Hal tersebut menunjukkan, bahwa pasien di puskesmas Proppo dapat diobati dengan chloramphenicol. Berikut merupakan hasil sensitifitas terhadap beberapa antibiotik dapat dilihat pada Tabel 2.

Tabel 2. Hasil analisis rata-rata zona hambat berdasarkan sensitivitas terhadap antibiotik berdasarkan Clinical and Laboratory Standart Institute

\begin{tabular}{ccccccc}
\hline \multirow{2}{*}{ Jenis Antibiotik } & \multicolumn{2}{c}{ Faktor yang ditinjau } & \multicolumn{3}{c}{ Keterangan } \\
\cline { 2 - 6 } & $\begin{array}{c}\text { Diameter } \\
(\mathbf{m m})\end{array}$ & $\begin{array}{c}\text { Kriteria } \\
\mathbf{( m m})\end{array}$ & Resisten & Sensitif & Intermediet \\
\hline Cholamphenicol & 24,0 & $19-26$ & - & $\sqrt{ }$ & - \\
Cefotaxime sodium & 10,9 & $25-31$ & $\sqrt{ }$ & - & - \\
\hline
\end{tabular}

Pada penelitian kali ini tidak ada penggunaan antibiotik yang intermediet, bisa jadi pola kuman sudah mengalami resisten terhadap antibiotik tersebut. 
Tampak terlihat di mana suatu keadaan mikroorganisme peka terhadap antibiotik, pada suatu medium tidak adanya zona hambatan atau diameter zona hambatnya berada pada rentang resisten. Selain faktor informatif tepat guna sasaran, resistensi terhadap penggunaan antibiotik juga ditengarahi oleh faktor geografis karena letak yang berbeda penggunaan antibiotik juga berbeda pula, oleh sebab itu screening pertama yang harus dilakukan dalam pemberian antibiotik selain informasi awal dilakukan dalam pemberian antibiotik selain informasi yang tepat sasaran dan juga analisa awal penting untuk dilakukan sehingga dalam pemberiaan antibiotik harus sesuai dengan kriteria yang dimaksud. Berikut merupakan persentase kepekaan antibiotik ke-4 spesimen pus isolat Staphylococcus aureus gram positif dapat dilihat pada Tabel 3.

Tabel 3. Pola kepekaan Staphylococcus aureus berdasarkan persentase terhadap beberapa antibiotik

\begin{tabular}{lcc}
\hline \multicolumn{1}{c}{ Kategori Kepekaan } & Jumlah isolat (n) & Persentase (\%) \\
\hline Resisten & 1 & 25 \\
Sensitif & 3 & 75 \\
Intremediet & 0 & 0 \\
Total & 4 & 100 \\
\hline
\end{tabular}

Berdasarkan penelitian Asati, RK (2013) menyebutkan bahwa sensitifitas penggunaan antibiotik Cholamphenicol mencapi $80.3 \%$, tertinggi ke-2 setelah Linezolid dan Gentamicin (86.7\%). Ini menandakan bahwa spesifikasi penggunaan antibiotik Cholamphenicol bisa digunakan sebagai salah satu alternatif sumber informatif yang tepat guna sasaran sebagai obat paten terhadap pasien yang terinfeksi piogenik hingga mengeluarkan nanah khususnya daerah Proppo.

\section{Kesimpulan}

Berdasarkan hasil penelitian yang telah dilakukan dapat disimpulkan sebagai berikut:

- Spesimen isolat pus yang diambil dari pasien puskesmas proppo termasuk bakteri Staphylococcus aureus, hal ini ditandai dengan bulatan berwarna ungu bergerombol sesuai dengan ciri khas,

- Sensitifitas bakteri terhadap penggunaan antibiotik Chloramphenicol ke-4 isolat memiliki daya hambat berturut-turut sebesar $23.5 \mathrm{~mm}, 24.2 \mathrm{~mm}, 24.0 \mathrm{~mm}$ dan 24.3 $\mathrm{mm}$. Hal tersebut menunjukkan sensitif terhadap Chloramphenicol dengan penggunaan responsif mencapai $75 \%$. Zona hambat terhadap Cefotaxime sodium masing-masing isolat adalah 5 $\mathrm{mm}, 10.5 \mathrm{~mm}, 14.5 \mathrm{~mm}$ dan $13,5 \mathrm{~mm}$ dengan penggunaan responsif mencapai $25 \%$ yang menunjukkan resisten terhadap penggunaan antibiotik tersebut.

- Berdasarkan hasil kuantitatif dari 4 spesimen isolat pus yang dianalisis, Cholamphenicol memiliki kepekaan responsif sangat besar mencapai $75 \%$ dibandingkan Cefotaxime sodium yang hanya mencapai $25 \%$.

\section{Ucapan Terima Kasih}

Daftar Isian Pelaksanaan Anggaran (DIPA) Deputi Bidang Penguatan Riset dan Pengembangan, Kementerian Riset dan Teknologi/Badan Riset dan Inovasi Nasional Nomor 032/AMD-SP2H/LTMONO PDPK/LL7/2021. 


\section{Daftar Pustaka}

Akhi, Akhi, M.T., Ghotaslou, R. Asgharzadeh, M., Varshochi, M., Pirzadeh, T., Memar, M.Y., Bialvaei, A.Z. Sofia, H.S.Y., Alizadeh, N, 2014. Bacterial Etiology and Antibiotics Susceptibility Pattern of Diabeteic Foot Infections in Tabriz Iran. GMS Hygiene and Infection Control. 10 : 1-6.

Androulla E., 1989. Outbreaks of Human Infections Caused by Pyogenic Streptococci of Lencefield Group C and G. Journal of Medical Microbiology. 29: 207-219.

Asati, RK., 2013. Antimicrobial Sensitivity Pattern of Staphylococcus aureus isolated from Pus Fromtertiary Care Hospital, Surendranagar, Gujarat and Issues Related to the Rational Selection of Antimicrobials. Sch. J. App. Med. Sci., 2013; 1(5):600-605.

Austin, T.X., 2021. Manitol salt agar. Austin Community College District. http://www.austincc.edu/microbugz/h tml/mannitol_salt_agar.html. [22-0321].

Brooks, Geo F., 2012. Jawetz, Melnick, \& Adelberg. Mikrobiologi Kedokteran. Edisi 25. Jakarta: EGC.

Budiman, HM., 2019. Prevalensi Kolonisasi Bakteri Methicillinresistant Staphylococcus aureus (MRSA) di ruang Intensive Care Unit (ICU) Rumah Sakit Umum Daerah Abdul Moeloek Bandar Lampung. Fakultas Kedokteran Universitas Lampung Bandar Lampung.

CLSI., 2018. Performance Standart for Antimicrobial Susceptilibity Testing; Twenty second informal supplement, 20th informational supplement. MI00S20-U. Wayne, PA CLSI.

Djide, 2010. Antimicrobial activities of tannins extract from guava leaves (Psidium guajavaL) on pathogens microbial.

Ekawati, E.R., Y. Husnul, S.N., Herawati, D., 2018. Identifikasi Kuman pada Pus dari Luka Infeksi Kulit. Jurnal
Sains Helth. Vol 2 No.1 Fakultas Ilmu Kesehatan Universitas Maarif Hasyim Latif Sidoarjo. p - ISSN : 2548 8333.

Hayati, LN., 2019. Isolasi dan Identifikasi Staphylococcus aureus pada Susu Kambing Peranakan Etawah Penderita Mastitis Subklinis di Kelurahan Kalipuro, Banyuwangi.

Jawetz, E., Melnick, J. L., Adelberg, E. A., 1991, Mikrobiologi untuk Profesi Kesehatan (Review of Medical Microbiology), Edisi ke-16, 148, 239294, EGC, Penerbit Buku Kedokteran, Jakarta.

Levinson, 2004. Global Mapping of the Yeast Genetic Interaction Network.

Price, S.A., dan Wilson, L. M., 1994, Patofisiologi: Konsep Klinis Prosesproses Penyakit, Edisi 6, Vol. 2, diterjemahkan oleh Pendit, B. U., Hartanto, H., Wulansari, p., Mahanani, D. A.,Penerbit Buku Kedokteran EGC, Jakarta.

Raytaker N.A., M.R. Choudari and S. Das., 2017. Antibiotic Profilling of Pseudomonas aeruginosa Isolates from Pus Sample of Rural Tertiary Care Hospital of Western Mahanashtra, Loni, India. Int. Jour. Of Research in Medical Sciences. 5(7): 3076-3081.

Singh, S., Khare, M., Patidar, R,K., Badge, S., Sahare, K.N., Dwivedi, D., Singh, V., 2013. Antibacterial Activities Against Pyogenic Pathogens. Int.Jour. Of Pharmaceutical Sciences and Research. 4(8):2974-2979.

Sukmawati, 2020. Isolasi Staphylococcus aureus pada Luka Infeksi Post Operasi serta penentuan Staphylococcus aureus resisten terhadap Methicillin.

Wahyuni, 2019. Isolasi dan Identifikasi Bakteri dari Sampel Pus dan Pola Sensivitas terhadap Antibiotik Penicillin, Cefuroxime dan Meropenen di RS Inco PT.Vale Sorowak. Fakultas Sains dan Teknologi UIN Alauddin Makassar. 